\title{
CORRELATION BETWEEN MICROVESSEL DENSITY AND MORPHOLOGICAL FEATURES IN SKIN SQUAMOUS CELL CARCINOMA
}

Lena Kakasheva-Mazhenkovska ${ }^{1}$, Neli Basheska ${ }^{2}$, Simonida Crvenkova ${ }^{3}$, Petrushevska Gordana ${ }^{4}$, Liljana Milenkova ${ }^{1}$, Vesna Janevska (senior) ${ }^{4}$, Vladimir Serafimoski ${ }^{5}$

${ }^{1}$ Institute of Medical, Experimental and Applied Histology and Embryology, Faculty of Medicine, "Ss. Cyril and Methodius" University, Skopje, Republic of Macedonia

${ }^{2}$ Department of Histopathology and Clinical Cytology, University Clinic of Radiotherapy and Oncology, Faculty of Medicine, "Ss. Cyril and Methodius" University, Skopje, Republic of Macedonia

${ }^{3}$ University Clinic of Radiotherapy and Oncology, Faculty of Medicine, "Ss. Cyril and Methodius" University, Skopje, Republic of Macedonia, Institute for radiotherapy and oncology, Skopje, Republic of Macedonia

${ }^{4}$ Institute of Pathology, Faculty of Medicine, Ss. Cyril and Methodius” University, Skopje, Republic of Macedonia

${ }^{5}$ Macedonian Academy of Sciences and Arts, Skopje, Republic of Macedonia

Corresponding Authors: Lena Kakasheva-Mazhenkovska, Institute of MEP Histology and Embryology, Skopje, R. Macedonia; E-mail: lena59kate@yahoo.com

\section{ABSTRACT}

Introduction. Abnormal angiogenesis is described in tumor growth and it facilitates its metastatic spread. Tumors with high angiogenic activity belong to the category of aggressive tumors with poor prognosis for patients. The aim of this study was to determine the blood vessels density (BVD), i.e. neovascularization at the tumor invasive front in skin squamous cell carcinoma (SCC) in order to determine its possible role in the tumor progression, and to correlate it to the blood vessels density of healthy skin and with the prognostic parameters of the TNM classification: T status, depth of tumor invasion (DI) and tumor histological grade (G), which were also correlated between each other.

Material and Methods. The material consisted of surgical specimens obtained from 30 patients with skin SCC, who underwent surgery.

Tissue samples were routinely processed by standard paraffin technique stained by Hematoxilin-Eosin and immunohistochemically with antibodies against smooth muscle actin (SMA) and CD34. The BVD in the invasive front of the neoplasms was correlated to the healthy skin, tumor status (pT), depth of invasion and grade of histological differentiation (pG).

Results. The histological analysis has shown a high statistical difference in the density of blood vessels in SCC compared to the healthy skin and statistical difference in BVD in neoplasms with different depth of invasion and different grade of differentiation. The density of neovascularzation increased with the deeper invasion and the worse differentiation.

Conclusion. The increased vascularization at the invasive front of SCC with deeper invasion and worse differentiation has pointed out to its possible role in neoplasm progression.

Key words: squamous cell carcinoma, immunohistochemistry, CD34, density of neovascularization, invasive front, histological differentiation

\section{INTRODUCTION}

Angiogenesis is a process of formation of new blood vessels from the preexisting normal capillaries in the tissue and occurs in physiological and pathological conditions. Abnormal angiogenesis is described in malignant neoplasms and it is considered that this angiogenesis sustains tumor growth and facilitates metastasis. When the metabolic needs of the tumor increase, the tumor gets an angiogenetic phenotype and begins to recruit blood vessels 
from the surrounding stroma. Neovascularization is crucial for the tumor growth and maintenance and removal of the degrading products of the metabolism. It is thought that tumors with a larger quantity of blood vessels are angiogenetic. Tumors with high angiogenic activity belong to the category of very aggressive tumors with poor prognosis for the patients $[1,2,3,4]$.

The first mechanism of tumor vascularization was named vascularization by sprouting $[5,6]$, a process that includes endothelial cells proliferation and migration from the existing blood vessels as well as organizing in tubular vascular structures. Later, some other mechanisms of tumor vascularization were discovered and named as: angioblast recruiting, co-opting vessels, vasculogenic mimicry and mosaic vessels $[7,8]$.

The new contemporary data of vascular biology identify some key factors that control the vascular growth and are included in the hypothesis suggesting that there is vascular inactivity in the normal tissues due to the dominant influence of endogenous angiogenic inhibitors despite the angiogenic stimulators.

In situations of disturbed balance when the secretion of angiogenic stimulators is increased and the regulation of endogenous angiogenic inhibitors is decreased, preconditions for tumor angiongenesis are developed $[6,7,9]$.

Numerous studies suggest a relationship between angiogenesis, or a vascular network density of the neoplasm and its progression $[4,10]$.

Preventing tumor growth by preventing tumor angiogenesis in the treatment of vascular and solid tumors of the skin such as SCC is a process with great potential in the treatment of neoplasms [11].

There are very few studies on angiogenesis in cutaneous SCC. From the literature focused on this field, we have found data pointing to an increased microvascular density during tumor progression [12], increased peritumoral microvascular density during neoplasm progression [13] or a significantly increased microvasculature in invasive SCC compared to the superficially invasive SCC and solar keratosis [12].

The purpose of this study is to show neovascularization in the invasive front of planocelular carcinoma of the skin to determine its density and to correlate it with the density of the blood vessels in healthy skin, the T status of the neoplasm, depth of invasion and the degree of histological differentiation of the tumor, and to determine the correlation of the individual parameters among themselves in order to determine the possible role of the microvascular density in the progression of SCC.
The aim of our study was to visualize the neovascularity and to determine the density of blood vessels at the invasive front of tumor stroma in skin SCC in relation to the healthy surrounding skin. Whether the change in the density of the neovascularization depends on the degree of histological differentiation of a neoplasm, whether there is influence of tumor stage and what kind of correlation there is between the blood vessels density and the depth of carcinoma invasion are questions we are going to try to give an answer to.

\section{MATERIALS AND METHODS}

This retrospective study included surgical specimens obtained from 30 patients with skin SCC, operated at the University Clinic of Plastic and Reconstructive Surgery and at the University Clinic of Maxillofacial Surgery in Skopje. The histological analysis of the surgical specimens was done at the Institute of Pathology, Medical Faculty in Skopje and at the Institute of Histology and Embryology, Faculty of Medicine, Skopje.

Archival materials were used in this study including: paraffin blocks, histopathological specimens and histopathological reports. Patients were grouped by sex, age and location of the neoplasm. Paraffin blocks were additionally used for making new histopathological sections from the carcinoma segment as well as from the resection margins of the surgical material, which were used as control groups for each patient separately. The sections taken for histopathological analysis were routinely examined and stained with hematoxylin-eosin. In addition, there was a special immunohistochemical staining using specific primary monoclonal antibodies against smooth muscle actin: (smooth muscle actin; aSMA (Dako /Clone 1A4/ Code M0851, dilution 1:100) и CD 34 (Dako /Clone QBEnd-10/Code M7165, dilution 1:50) using Avidin-Biotin Immunoperoxydase Complex technique. For the visualization of the antigen-antibody reaction, LSAB and En-Vision kits from DAKO were used.

In the slides stained with antibody against CD34 at a low magnification $(10 \times 4)$ certain areas of the greatest vascular density (hot spots) in the invasive front of the neoplasm were identified, while at a high magnification of $x 400$ (Fig. 4) the well-formed vascular channels were counted, with a clearly differentiated lumen, along the invasive front, in a set of 10 visual fields. Immunostaining with smooth muscle actin (SMA) was used in order to prove the presence of non-capillary blood vessels that contain smooth muscle cells in their wall as well as to visu- 
alize blood vessels in the normal dermis serving as a control for staining with CD34. The procedure for density determination was identical with that applied in staining with CD34 (Fig. 1, 2, 3).

The depth of stromal invasion in each case is measured by software for histomorphometry LUCA $\mathrm{M}$ on the microscope Olimpus BX-41. The distance from the basement membrane of the epidermis to the deepest invasive beach front is accounted for and measured. The resulting values are absolute numbers expressed in micro meters $(\mu \mathrm{m})$.

The grade of histological diferentiation $(\mathrm{G})$ and tumor local growth/status (pT) were taken from preexisting histopathological reports. [14], (Fig. 4, 5, 6).

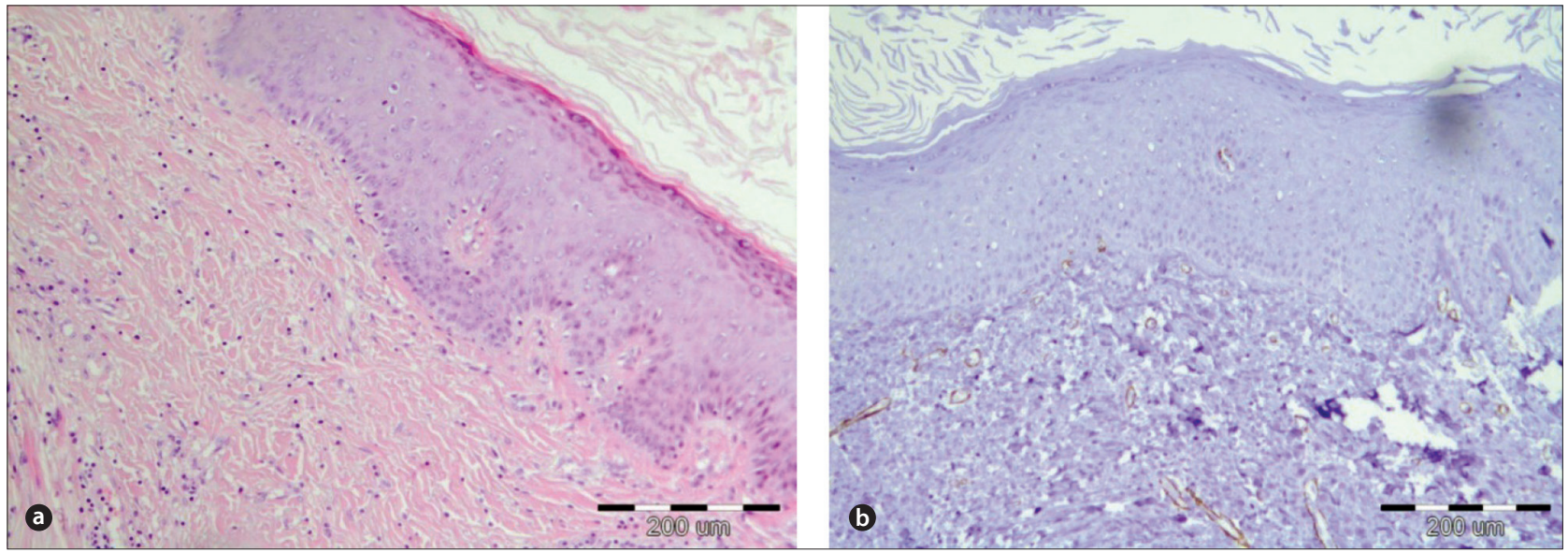

Figure 1. Microphotographs: a) Normal skin H.E. $(10 \mathrm{x} 4)$ b) Normal skin Immunostaining with CD34 (10x4)
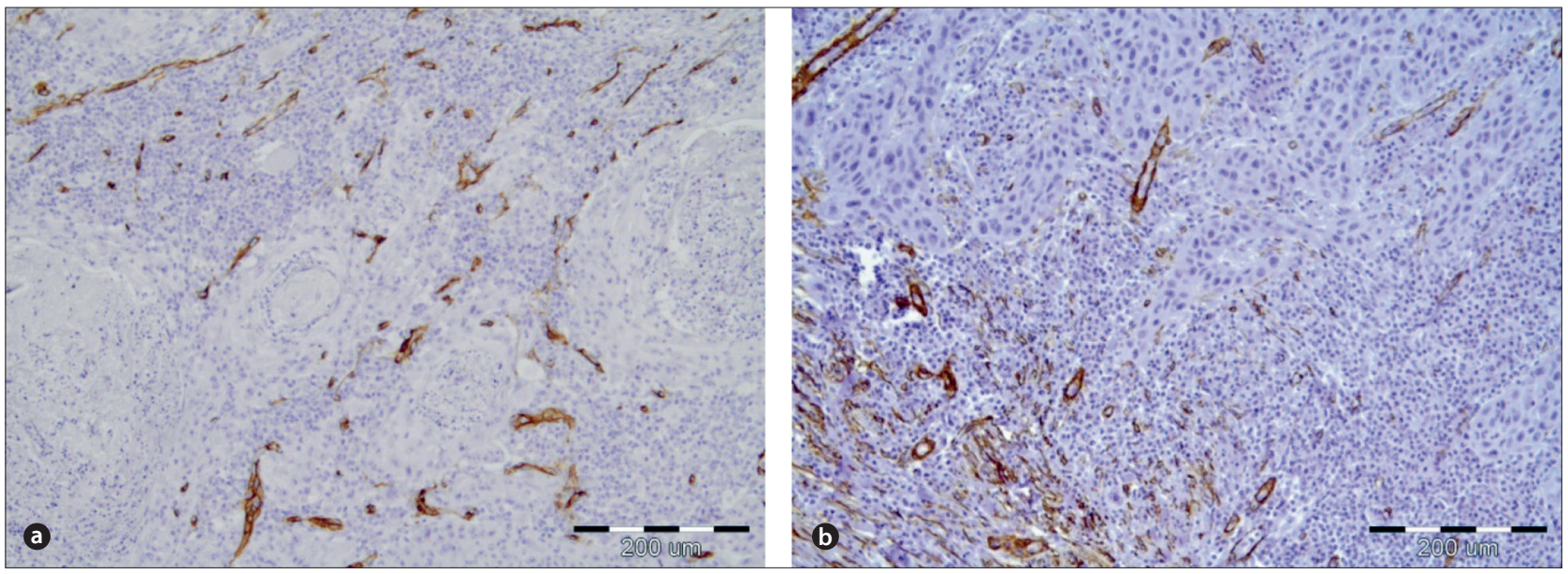

Figure 2. Microphotographs. a) Immunostaining with CD34 (10x10). b) Microvessel density in the invasive front of G2 SCC (CD34 10x10)
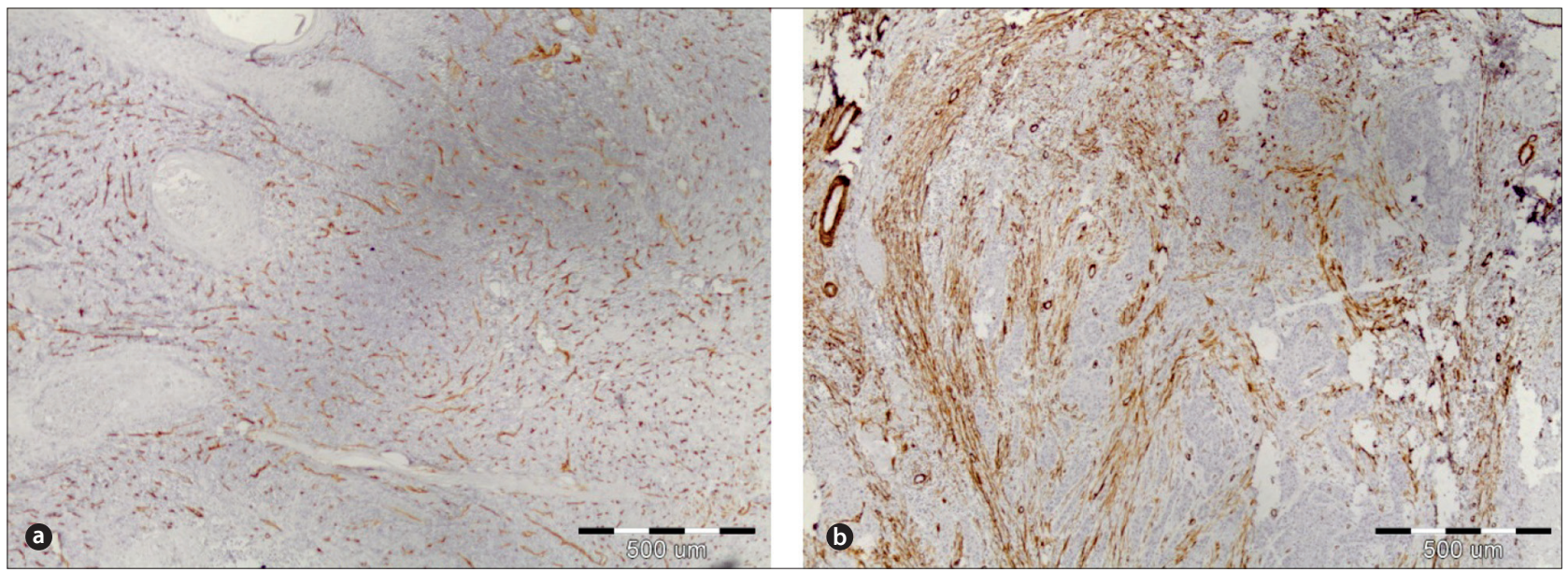

Figure 3. Microphotographs. a) Microvessel density in G3 SCC Actin (10x4) b) Microvessel density, immunostaining with Actin (10x10) 


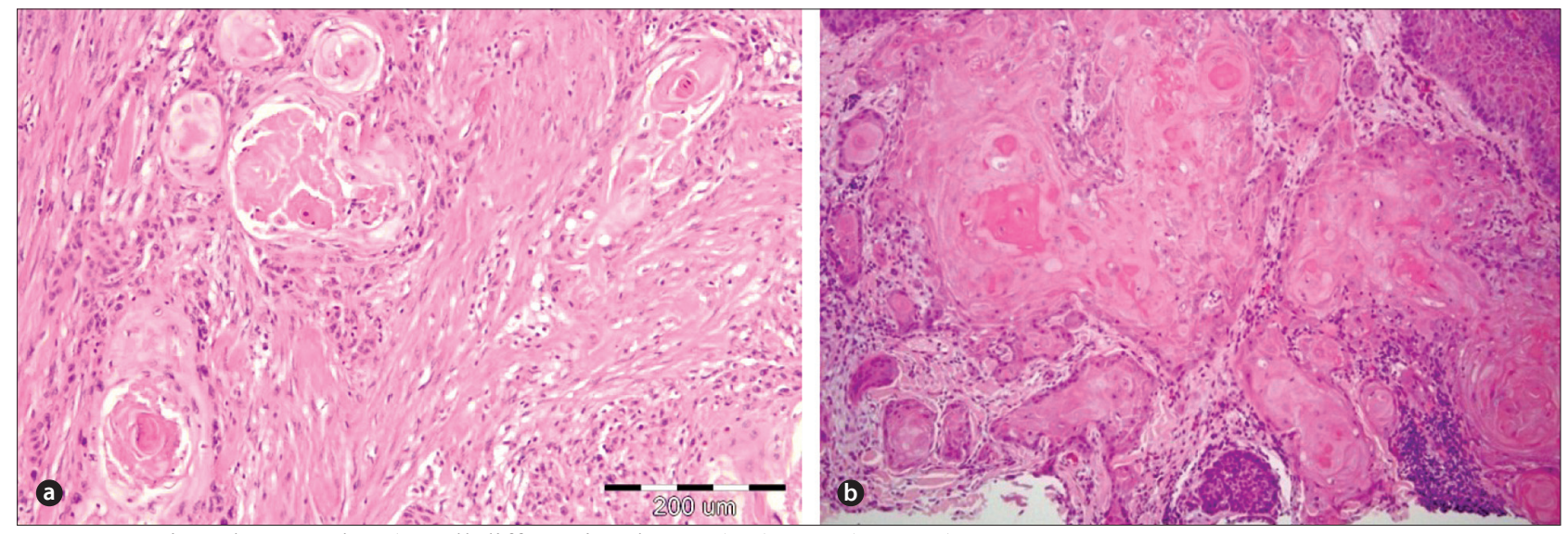

Figure 4. Microphotographs. a) Well differentiated SCC (G1) H.E. (10 x 10)

b) Another case of well differentiated SCC H.E. $(10 \times 10)$
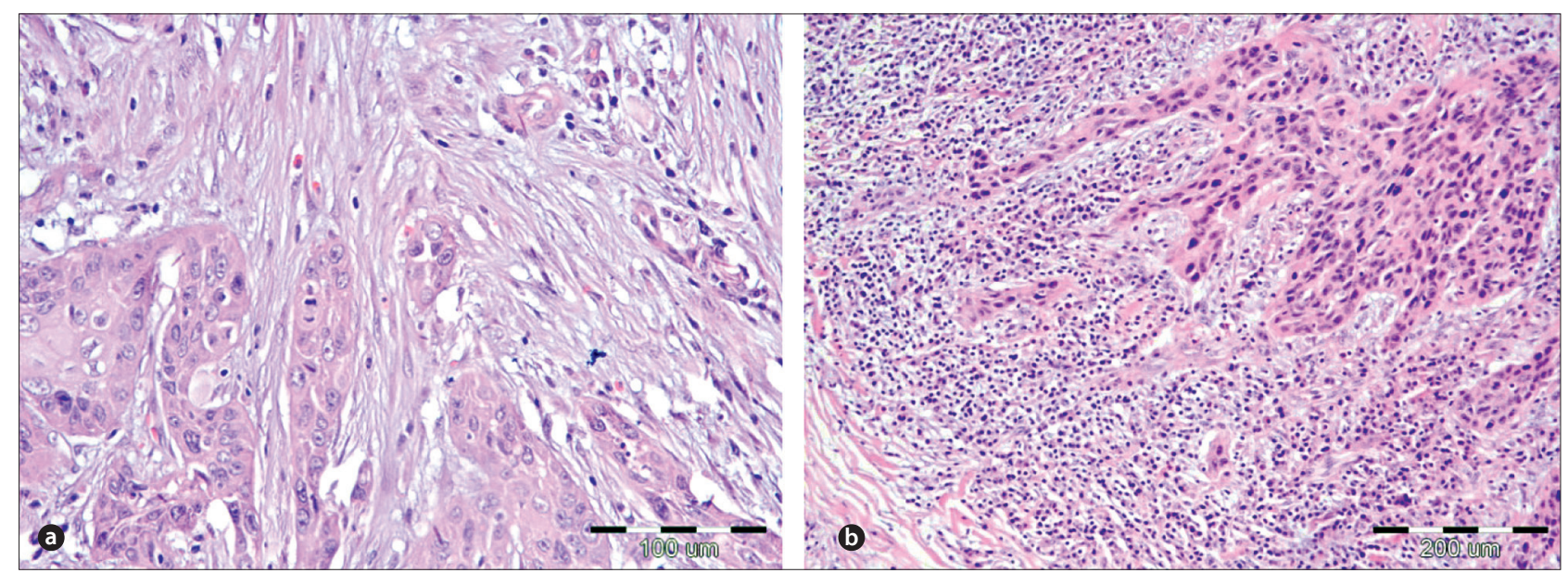

Figure 5. Microphotographs. a) Invasive front of a moderate differentiated SCC (G2) H.E. (10x20)

b) The invasive front of an another case of a moderate differentiated SCC) H.E. (10x10)
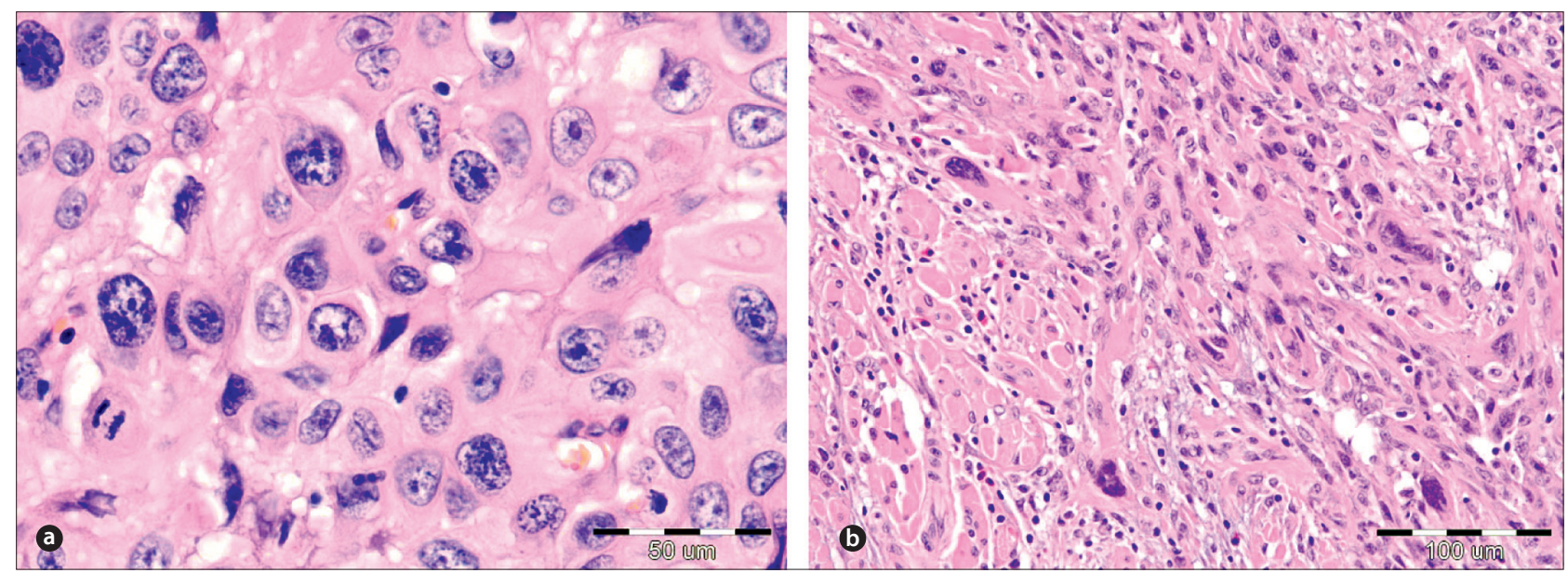

Figure 6. Microphotographs. a) Poorly differentiated SCC (G3) H.E. (10x40)

b) Invasive front of poorly differentiated SCC H.E. (10x20)

The density of the neovascularization in each separate case was determined as a sum of all stained and counted vascular lumina found in the 10 visual fields. Both, the minimum and the maximum count of blood vessels were determined (from all visual fields) in each case and their mean value was calculated. Identical procedure was conducted on the sections from the surrounding healthy skin, involving determination of the vessel density in the dermis.

For the evaluation of the results modern statistical methods of analyses were used by employing the computer software. The statistical package SPSS 11.0 was used for creation of databases. The following statistical tests were applied: 
- Kruskal-Wallis test,

- Mann Whitney U test is an equivalent to Student's t-test;

- Spearman's rank correlation

\section{RESULTS}

Of the total number of 30 analyzed patients, 10 $(33.3 \%)$ were females, aged $70-98$ years (mean age $85.7 \pm 8.4)$, whereas $20(66.7 \%)$ were males, aged $57-89$ years (mean age $74.2 \pm 10.4$ ) (Table 1 ).

The most frequently present skin region in the examined group was the face, in 13 cases (43.3\%), and the least present were regions of the forehead, neck, breast, eyelid, arm, and leg with one case each (3.3\%) (Table1).

There were 21 cases $(70.0 \%)$ with pT1 tumors and 9 cases $(30.0 \%)$ with pT2 tumors (Table 1$)$ and there were $12(40.0 \%)$ G1 tumors, $13(43.3 \%)$ G2 tumors and 5 (16.7\%) G3 tumors (Table 1).

Values obtained by measuring the depth of invasion ranged from the lowest $1561.2 \mu \mathrm{m}$ to the highest $13000.1 \mu \mathrm{m}$, mean value 4991.71 \pm 1741.9 (Table 1).

The depth of the stromal invasion was the smallest in well-differentiated (G1) squamous cell carci-

Table 1. Distribution of cases according to: location, tumor status of the neoplasm (pT), grade of differentiation $(\mathrm{G})$ and depth of invasion

\begin{tabular}{|c|c|}
\hline Location & Number and \% \\
\hline Skin of face & $13(43.33 \%)$ \\
\hline Skin of nose & $3(10.0 \%)$ \\
\hline Skin of ear auricle & $3(10.0 \%)$ \\
\hline Skin of abdomen & $3(10.0 \%)$ \\
\hline Skin of scalp & $2(6.66 \%)$ \\
\hline Skin of forehead & $1(3.33 \%$ \\
\hline Skin of eyelid & $1(3.33 \%)$ \\
\hline Skin of neck & $1(3.33 \%)$ \\
\hline Skin of breast & $1(3.33 \%)$ \\
\hline Skin of hand & $1(3.33 \%)$ \\
\hline Skin of lower limb & $1(3.33 \%)$ \\
\hline Tumor status (pT) & Number and \% \\
\hline pT1 & $21(70.0 \%)$ \\
\hline pT2 & $9(30.0 \%)$ \\
\hline Gum & Number and \% \\
\hline G2 & $12(40.0 \%)$ \\
\hline G3 & $13(43.33 \%)$ \\
\hline Depth of invasion & $5(16.66 \%)$ \\
\hline & mean $\pm \mathbf{s d}$ \\
\hline Depth of invasion & $4991.71 \pm 2741.9 \mu \mathrm{m}$ \\
\hline & min. / max. \\
\hline & $1561.2 \mu \mathrm{m} / 13000.1 \mu \mathrm{m}$ \\
\hline
\end{tabular}

nomas (mean 2579.28 \pm 697.26 ), and the largest in the poorly differentiated (G3) squamous cell carcinomas (mean 9219.896 \pm 2268.882 ) (Table 2).

Table 2. Average depth of stromal invasion in skin SCC expressed in micrometers according to the grade of differentiation $(\mathrm{G})$ of neoplasms

\begin{tabular}{|c|c|}
\hline $\begin{array}{c}\text { Grade of } \\
\text { differentiation }\end{array}$ & $\begin{array}{c}\text { Depth of stromal } \\
\text { invasion }(\boldsymbol{\mu m})\end{array}$ \\
\hline $\mathrm{G} 1(\mathrm{~N}=12)$ & $2579.28 \pm 697.26$ \\
\hline $\mathrm{G} 2(\mathrm{~N}=13)$ & $5592.33 \pm 1532.48$ \\
\hline $\mathrm{G} 3(\mathrm{~N}=5)$ & $9219.896 \pm 2268.882$ \\
\hline
\end{tabular}

The difference in depth of the stromal invasion in skin SCC, which was registered in neoplasms with different grade of histological differentiation, was statistically significant (Kruskal-Wallis test: H (2, $\mathrm{N}=30)=23.47711, \mathrm{p}=0.00008)$ (Figure 7).

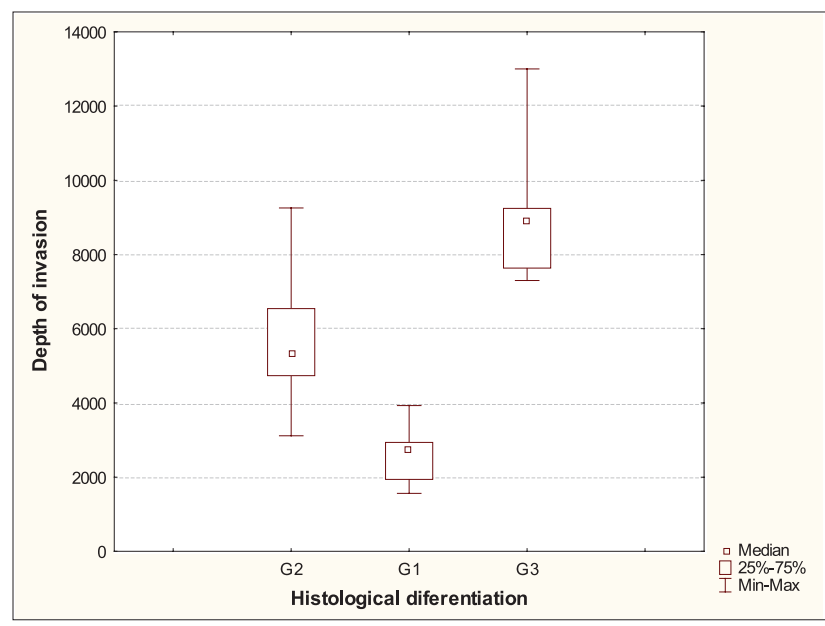

Legend: (G1) - well-differentiated carcinoma, (G2) - moderately differentiated carcinoma, (G3) - poorly differentiated carcinoma Figure 7. Statistically significant difference between the depth of invasion in skin SCC with different grade of differentiation

The depth of stromal invasion differed in neoplasms with different tumor stage (pT).

Table 3 shows that in pT1 neoplasms smaller or equal to $2 \mathrm{~cm}$ the depth was smaller (3957.534 \pm 1843.46$)$ than in pT2 neoplasms larger than $2 \mathrm{~cm}$ where the depth of the stromal invasion was 7404.770 $\pm 3066.01(\mathrm{p}<0.05$ (Mann-Whitney U test- $\mathrm{z}=2.96429 \mathrm{p}=0.003034)($ Figure 8$)$

Table 3. Average depth of stromal invasion in skin SCC expressed in micrometers according to the tumor status (pT1 and pT2) of the neoplasm

\begin{tabular}{|c|c|}
\hline $\begin{array}{c}\text { Tumor status } \\
\text { of neoplasm }\end{array}$ & $\begin{array}{c}\text { Depth of stromal } \\
\text { invasion }(\boldsymbol{\mu m})\end{array}$ \\
\hline $\mathrm{T} 1(\mathrm{~N}=21)$ & $3957.534 \pm 1843.468$ \\
\hline $\mathrm{T} 2(\mathrm{~N}=9)$ & $7404.770 \pm 3066.009$ \\
\hline
\end{tabular}




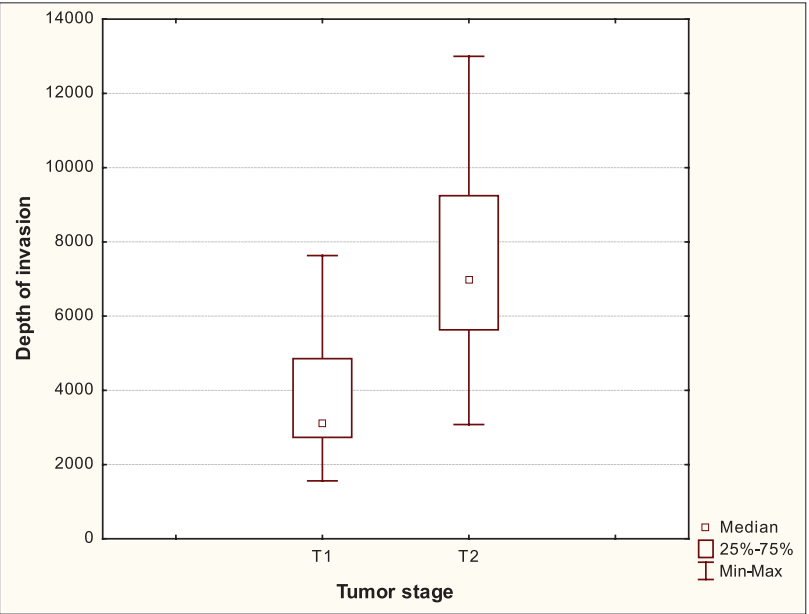

Legend: (pT1) - tumor size smaller or equal to $2 \mathrm{~cm}(\mathrm{~T} 1 \leq 2 \mathrm{~cm})$, (pT2) - tumor size larger than $2 \mathrm{~cm}(\mathrm{~T} 2>2 \mathrm{~cm})$

Figure 8. Statistically significant difference between depth of invasion in skin SCC of skin in neoplasms with pT1 and $\mathrm{pT} 2$ tumor status

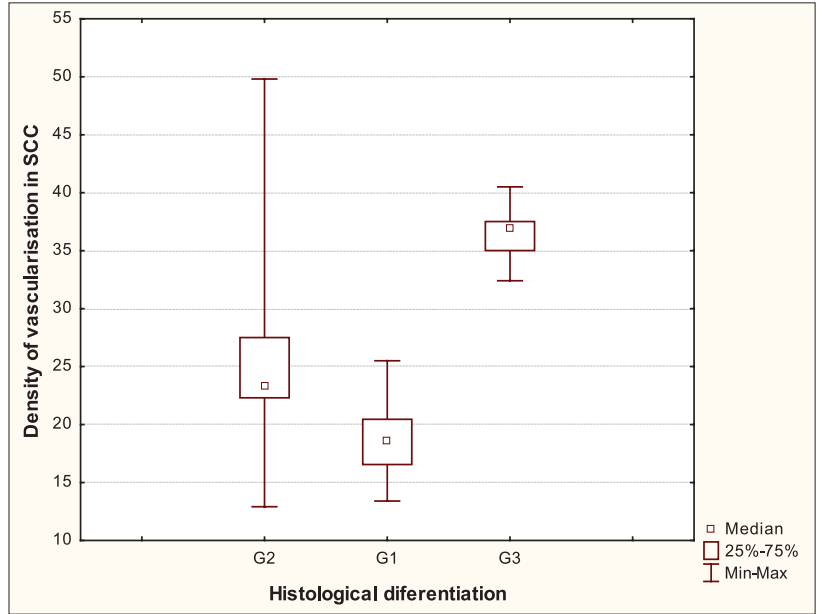

Legend: (G1) - well-differentiated carcinoma, (G2) - moderately differentiated carcinoma, (G3) - poorly differentiated carcinoma

Figure 9. Statistically significant difference in the density of neovascularization in skin SCC according to the grade of histological differentiation (G1, G2, G3)

Table 4. Vascular density in the invasive front of skin SCC and the normal surrouding skin and grade of diferentiation of the neoplasms $(\mathrm{G})$

\begin{tabular}{|l|c|c|c|}
\hline & G1 $(\mathbf{N}=\mathbf{1 2})$ & G2 $(\mathbf{N}=\mathbf{1 3})$ & G3 $(\mathbf{N}=\mathbf{5})$ \\
\hline Total number of blood vessels in visual field & $187.92 \pm 37.99$ & $256.61 \pm 83.34$ & $364.80 \pm 30.13$ \\
\hline Minimum number of blood vessels in visual field & $15.08 \pm 3.44$ & $13.07 \pm 2.53$ & $17.40 \pm 4.16$ \\
\hline Maximum number of blood vessels in visual field & $24.75 \pm 5.59$ & $33.0 \pm 9.88$ & $39.0 \pm 4.63$ \\
\hline Mean number of blood vessels in visual field \pm SD & $18.79 \pm 3.79$ & $25.44 \pm 8.43$ & $36.48 \pm 3.01$ \\
\hline \multicolumn{2}{|l|}{ Vascular density in normal surrounding skin } \\
\hline Total number of blood vessels in visual field & $66.33 \pm 15.95$ & $68.61 \pm 9.13$ & $63.20 \pm 8.70$ \\
\hline Minimum number of blood vessels in visual field & $4.16 \pm 1.19$ & $4.92 \pm 2.10$ & $3.80 \pm 1.78$ \\
\hline Maximum number of blood vessels in visual field & $12.33 \pm 3.20$ & $13.69 \pm 3.22$ & $11.60 \pm 3.28$ \\
\hline Minimum number of blood vessels in visual field \pm SD & $6.63 \pm 1.59$ & $6.86 \pm 0.91$ & $6.32 \pm 0.87$ \\
\hline
\end{tabular}

The lowest value of vascular density in the invasive front of the neoplasm was found in the well-differentiated tumors (G1), and the highest value was found in the poorly differentiated tumors (G3). The mean values of the vascularization were in range of 15.8 to 24.75 blood vessels (Table 4) and they showed statistically significant difference of BVD in the groups of carcinomas with different grade of differentiation (Kruskal-Wallis test: $\mathrm{H}(2$, $\mathrm{N}=30$ ) $=16.02890, \mathrm{p}=0.0003$ ) (Figure 3).

The difference registered in the mean values of vascular density in tumors compared to that in normal skin was statistically significant (Mann-Whitney U test- $\mathrm{z}=6.652991, \mathrm{p}=0.0000001$ ) (Figure 10).

Neovascular density in the invasive front of the neoplasm in terms of tumor status was different but not statistically significant (Mann-Whitney U test-Z $=1,42557, \mathrm{p}=0.153993$ ).

With regard to tumor stage $(\mathrm{pT})$ of neoplasms with SCC, no statistically significant difference in the density of vascularization was observed be-

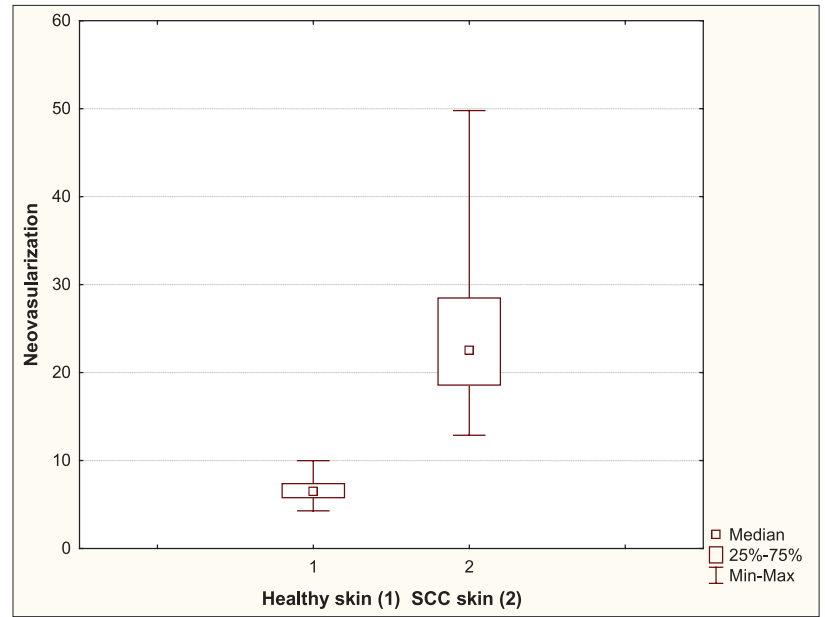

Legend: 1 - healthy skin, 2 - carcinoma

Figure 10. Statistically significant difference in density of neovascularization in skin SCC compared to the density of vascularization in normal surrounding skin

tween the tumors measuring $\mathrm{T} 1 \leq 2 \mathrm{~cm}$ and $\mathrm{T} 2>2$ cm (Mann-Whitney U тест- $\mathrm{z}=1.42557, \mathrm{p}=0.153993$ ) (Figure 5). 
Table 5. Mean density of vascularization according to tumor status (pT) of the neoplasm

\begin{tabular}{|c|c|}
\hline $\begin{array}{c}\text { Tumor status } \\
\text { of neoplasm }\end{array}$ & $\begin{array}{c}\text { Density } \\
\text { of vascularization }\end{array}$ \\
\hline $\mathrm{pT} 1(\mathrm{~N}=21)$ & $23.63 \pm 9.27$ \\
\hline $\mathrm{pT} 2(\mathrm{~N}=9)$ & $26.93 \pm 6.88$ \\
\hline
\end{tabular}

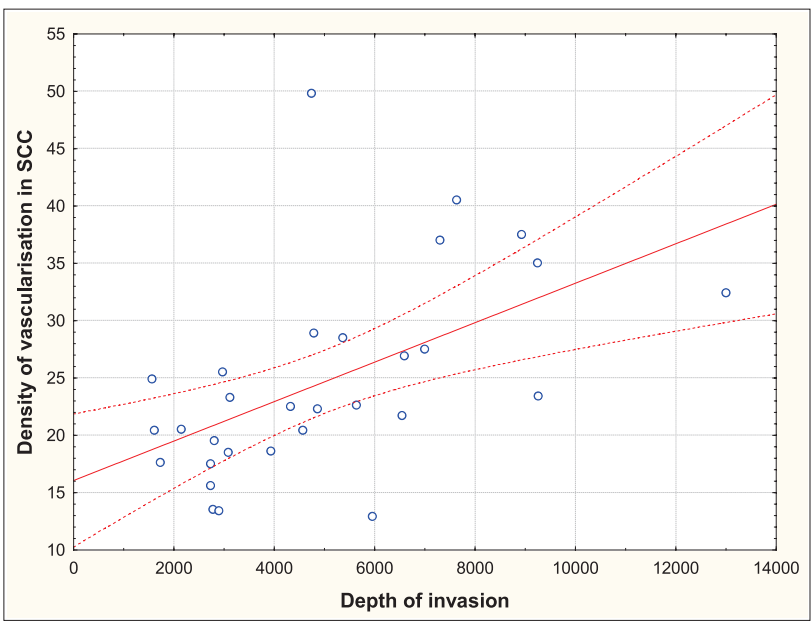

Figure 11. Correlation of the vascular density in the invasive front of the SCC of the skin and the depth of invasion

The density of the neovascularization in SCC of the skin was in positive statistically significant correlation to the neoplastic depth of invasion (Spearman Rank Order Correlations- $\mathrm{r}=0,5455, \mathrm{p}=0,00018$ (Figure 11).

The statistical analysis of the examined parameters: tumor status ( $\mathrm{pT} 1 / \mathrm{pT} 2)$, grade of histological differentiation (G1, G2, G3), depth of invasion and density of blood vessels at the invasive front of skin SCC according to the sex and age of the patients as well as according to location of neoplasms showed no statistical significance.

\section{DISCUSSION}

The blood vessels in the healthy human skin are usually passive and in general the neovascularization is not noticed except in follicular angiogenesis which is included in the separate phases of follicle cycle. The normal dermal matrix in the area of the base membrane around the microvascular endothelial cells are thought to function as a natural inhibitor of angiogenesis, ensuring the passivity of the blood vessels in healthy skin [15].

Recent data show that thrombospondin-1 (TSP1) and 2-thrombospondin (TSP-2) are the main physiological inhibitors of dermal angiogenesis. TSP-1 and TSP-2 are members of the matrix glycoprotein family and deposit in the dermal-epidermal basal membrane, which promotes an angiogenetic barrier by separation of the non-vascularized epidermis from the vascularized dermis. Endostatin, angiostatin, vasostatin and interleukin 12 (IL-12) play the same role. They are together identified as inhibitors of tumor angiogenesis and tumor growth in vivo $[9,15]$.

Potent pro-angiogenic factors in the skin angiogenesis are the following: vascular endothelial growth factor (VEGF-A), basic fibroblast growth factor (bFGF-2) and interleukin-8 (IL-8). VEGF-A is the main angiogenic growth factor which is bound to two types of tyrosine receptors VEGFR-1 and VEGFR-2 that can be found in vascular endothelial cells. VEGF-A is secreted by tumor cells and influences upon releasing of matrix metalloproteinases (MMPs) from endothelial cells. The released MMP-2 and MMP-9 degrade the extracellular matrix (ECM) tracing invasive pathway of endothelial cells in the neighboring tissue. Additionally MMPs dissolve ECM by which new concentrations of bFGF-2 and VEGF-A are released [9,10,15,16, 17]. In situations of disturbed balance when the secretion of angiogenic stimulators is increased and the regulation of endogenous angiogenic inhibitors is decreased, preconditions for tumor angiongenesis are developed $[6,7,9]$.

In the early 70s Judah Folkman postulated the hypothesis that tumors need vascularization in order to grow and that some diffusible molecules regulate that process. The process of onset of angiogenesis is balanced by pro- and anti-angiogenic factors. At the same time, he believed that perhaps by disturbing and preventing angiogenesis in tumors, the tumor growth would be slowed down, the tumor mass would be decreased and tumor regression would appear $[17,18,19]$.

Inhibition of angiogenesis would include: inhibition of angiogenic growth factor production, increased production of angiogenic inhibitors or inhibition of receptors' activity and signaling of blood vessels [20, 21, 22].

Not all tumors are angiogenic from the beginning of their growth. Clinical and experimental data about formation of tumors influenced by chemical cancerogenic substances, confirm that tumor progression happens by a switch from a prevascular to a vascular phase. The first data about the angiogenic potential of premalignant lesions came from the Folkman's laboratory where the transition from hyperplasia to neoplasia was shown.

Premalignant lesions can be found in all epithelial organs and are characterized by disordered proliferation, loss of cell uniformity and architecturally different organization. Some changes are reversible, but some develop further on towards carcinoma in situ and then in invasive carcinoma [23, 24]. 
The activation of vascularization in premalignant lesions is characterized by proliferation and migration of endothelial cells and by the ingrowth of new blood vessels from the preexisting ones, by which higher density of the new blood vessels is evident, while together with the increased expression of VEGF-A/VEGFR-2 and decline of TSP-1 are indicators for the early angiogenic switch or inclusion of angiogenesis in skin squamous cell carcionoma (SCC). Growth factors from the VEGF family play a fundamental role in the growth and invasion of SCC. The blockage of VEGFR-2 receptors leads to inhibition of angiogenesis and invasion of SCC. The levels of TSP-1 and TSP-2 physiologic inhibitors of skin angiogenesis, located on the basement membrane, are decreased in SCC, which has shown to be an indicator or phase that precedes the invasion. Studies have shown deletion of the chromosome 15 , which is the location of the gene TSP-1. In the experimental studies there are proofs that if a copy of the chromosome 15 is added or TSP-1 is given, tumor growth will be suppressed $[25,26]$.

The accumulated scientific-research data on the human body confirm that angiogenic intensity can be a prognostic indicator in numerous malignomas including: head and neck SCC, malignant melanoma, cancers of the lungs, breast, stomach, urinary bladder, prostate, cervix and invasive skin SCC and indicated the relationship between angiogenesis, i.e. density of the vascular net in a neoplasm and its progression which is associated with tumor aggressiveness and poor prognosis. Disabling tumor growth by preventing tumor vascularization i.e. angiogenesis, represents an oncologic therapeutic approach to the treatment of vascular and solids following the consistency of skin tumors such as SCC [27].

Angiogenesis in SCC has been examined in tumors that occur in several different anatomic sites in order to determine its role in progression of tumors or their aggressiveness and consequently the outcome of the disease [28]. Analysis of angiogenesis in solar keratosis, in superficially invasive and invasive SCC of the skin, has shown higher microvessel density compared to the neighboring normal skin, pointing out to the fact that angiogenesis appears early in the developmental stage of cutaneous SCC and that neovascularization is parallel with the tumor progression [29].

The analysis of the microvascular density in SCC and basal cell carcinoma of the skin, using immunostaining with CD34 and determination of the levels of VEGF, showed that the correlation between the high vascular density and high level of VEGF in SCC indicate a possible role of angiogenesis in de- termining more aggressive types of cancers [30,31]. The vascular density is confirmed to be higher in SCC than in basal cell carcinoma. The association of microvascular density and neck metastasis in oral SCC points on the key role of angiogenesis in oral SCC [32].

However, a variety of data can be found in the literature. One study conducted on head and neck malignant tumors presented correlations between vessel density, bad prognosis and onset of metastases $[33,34]$, while another study found no correlation between angiogenesis and tumor stage and prognosis [35]. It is still unclear whether these discrepancies due to different tumor stages, localization or methods of analysis [36].

The rate of metastasis in skin SCC is low and ranges from $4.5 \%$ in tumors of thickness (depth of invasion) between $2-6 \mathrm{~mm}$ and $15 \%$ in tumors exceeding a thickness of $6 \mathrm{~mm}$ [37]. In the absence of generally accepted criteria for evaluation of the early stages of SCC Breuninger's classification has been accepted, which is more relevant than Broder's one and which is based on the degree of differentiation [38]. Based on Breuninger's classification of carcinomas of thickness $<2 \mathrm{~mm}$, no increased vessel density was observed. Only in carcinomas exceeding a thickness of $2 \mathrm{~mm}$ the vascular density was significantly increased. The location of the tumor did not have influence on the vascular density, but had an impact on the depth of infiltration into the subendothelial stroma [39].

This suggests that in skin SCC the increased vascular density might be a prognostic factor and together with the disease stage might be an indicator of tumor aggressiveness and disease outcome [40]. Discrepancies between data presented in the literature may be due to: origin of the specimens (human or animal), different dynamics of tumor progression, different causes that influence on tumor development, i.e. virally- or ultraviolet-induced carcinogenesis. On the other hand, skin epithelial tumors remain surface tumors for a considerable period and may not require increased angiogenesis since they are completely well-nourished by diffusion similar to the epidermis. Increased angiogenesis would be required if tumor mass increases and consequently hypoxia increases in that area [41].

Taking into consideration that in the skin SCC, determining the $\mathrm{T}$ parameter of pTNM classification means measurement of the largest diameter of the neoplasm, which is not always identical to the one that determines the depth of the invasion, many authors have tried to explore the depth of invasion of $\mathrm{SCC}$ as a prognostic factor. [42,43]. 
Tan WJ and others have investigated the prognostic significance of the depth of the invasion in carcinoma of the tongue and found that it is an important prognostic indicator in cancer of the tongue [44].

In another research the prognostic factors in penile SCCs were analyzed. It was found that the depth of the invasion and the vascular invasion were significant predictors of cancer progression [45].

Kristensen GB et al. determined the major prognostic factors in early SCC of the uterine cervix and discovered that the clinical tumor size and depth of invasion were the main prognostic factors in patients with early squamous cell cervical carcinoma [46].

\section{CONCLUSION}

The analysis of this study showed significant increase of the microvascular areas in an invasive front of SCC compared to the normal skin and showed correlation between the density of the neovascularization, the depth of the invasion and the grade of neoplasm, elements which according to numerous authors represent predictors of tumor progression.

Neovascularization significantly increases in neoplasm with higher grade and the higher depth of invasion. Hence, the increase in vascularity in worse differentiated carcinomas influences the depth of invasion and it plays a role in the progression of the neoplasm.

The significant change in the vascular density of SCC in contrast to the normal skin and its gradual increase in tumor stroma of cancers with worse differentiation and incised depth of invasion suggests that neoangiogenesis is a process that is associated with the needs of the neoplasm, i.e. it facilitates its spread.

\section{REFERENCES}

1. Gijatromanolaki A, Sivridis E, Koukourakis M.Tumour angiogenesis:vascular growth and survival. APMIS. 2004;112:431-440.

2. Rowe DE, Carroll RJ, Day CL. Prognostic factors for local recurrence, metastasis and survival rates in squamous cell carcinoma of the skin, ear, and lip. J Am Acad Dermatol 1992;26(6):976-990.

3. Sharma S, Sharma MC, Sarcar C. Morphology of angiogenesis in human cancer: a conceptual overview, histoprognostic perspective and significance of neoangiogenesis. Histopathology 2005;46:481-489.

4. Larsen M, Artym VV, Green JA, Yamada KM. The matrix reorganized:extracellular matrix re- modeling and integrin signaling. Curr Opin Cell Biol 2006; 18:463-471.

5. Kerbel RS. Tumor angiogenesis. N Engl J Med 2008; 358:2039-49.

6. Auguste P, Lemiere S, Lahargue FL, Bikfalvi A. Molecular mechanisms of tumor vascularization. Crit Rev Oncol Hematol 2004;54:53-63.

7. Lamalice L, Le Boeuf F, Huot J. Endotelial cell migration during angiogenesis. Cirk Res 2007;100:782-794.

8. Gerhart H, Betsholtz CH. Endothelial-pericyte interactions in angiogenesis. Cell Tissue Res 2003;314:15-23.

9. Bremnes RM, Donnem T, Al-Said S, Al-Shibly K, Andersen S, Sirera R, Camps C, Marinez I, Busund LT. The role of tumor stroma in cancer progresion and prognosis. J Thorac Oncol 2011;6:209-217.

10. Verdolini R, Amerio P, Goteri G, Bugatti L, Lucarini G, Mannello B, Filosa G, Offidani A, Brancorsini D, Biagini G, Giangiacomi M. Cutaneous carcinomas and preinvasive neoplastic lesions. Role of MMP-2 and MMP-9 metalloproteinases in neoplastic invasion and their relationship with proliferative activity and p53 expression. J Cutan Pathol 2001; 28: 120-126.

11. Kyzas PA, Stefanou D, Batistatou A, Agnantis NJ.Potential autocrine function of vascular endothelial growth factor in head and neck cancer via vascular endothelial growth factor receptor-2. Mod Pathol 2005;18:485-494.

12. Florence MEB, Massuda JY, Bröcker EB, Metze K, Cintra ML, De Souza EM. Angiogenesis in the progression of cutaneous squamous cell carcinoma: an immunohistochemical study of endothelial markers. Clinics (SaoPaolo) 2011;66(3):465-468.

13. Shieh YS, Lee HS, Shieh SG,Chu YW, Wu $\mathrm{CW}$, Chang LC. Role of angiogenic and non-angiogenic mechanisms in oral squamous cell carcinoma: correlation with histological differentiation and tumor progression. J Oral Pathol Med 2004;33(10):601-6.

14. Edge SB., Byrd DR., Compton CC., Fritz AG., Greene FI., Trotti A. Cancer staging handbook: from the AJCC cancer stading manual, AJCC editors $7^{\text {th }}$ edition. Springer, New York: 2010 p.359-375.

15. Velasco P, Lange-Asschenfeldt B. Dermatological aspects of angiogenesis. Br J Dermatol 2002; 147:841-852. 
16. Bergers $\mathrm{G}$, Benjamin LE. Tumorigenesis and the angiogenic switch. Nat Rev Cancer 2003;3:401410.

17. Yorioka CW, Coletta RD, Alves F, Nishimoto IN, Kowalski LP, Graner E. Matrix metalloproteinase-2 and -9activities correlate with the disease-free survival of oral squamous cell carcinoma patients. Int J Oncol 2002; 20(1):189-194.

18. Folkman J. Role of angiogenesisin tumor growth and metastasis. Semin Oncol 2002; 29(16):15-8.

19. Folkman J.Fundamental concepts of the angiogenetic process. Curr Mol Med.2003;3:643-651.

20. Folkman J,Kalluri R. Tumor angiogenesis.In: Kufe DW. Pollock RE, Weichselbaum RR, Bast RC, Gansler TS, Holland JF, Frei E, editors. Cancer Medicine $6^{\text {th }}$ edition.Hamilton:BC Decker,2003.

21. Folkman J. Angiogenesis. Annu Rev Med 2006;57:1-18.

22. Ribatti D. Judah Folkman, a pioneer in the study of angiogenesis. Angiogenesis 2008:11:3-10.

23. Raica M, Cimpean AM, Ribatti D. Angiogenesis in pre-malignat conditions. Eur J Cancer2009;45:1924-1934.

24. Abulafia O, Triest We, Sherer DM. Angiogenesis in squamous cell carcinoma in situ and microinvasive carcinoma of the uterine cervix. Obset Gynecol 1996;88(6):927-32.

25. Gijatromanolaki A, Koukourakis M, Sivridis E, Thore PHE, Brekken RA, Konstantinos S, Fountzilas G, Gatter KC, Haris AL. Tumor specific activation of the VEGF/KDR angiogenic pathway in a subset of locally advanced cell head and neck carcinomas. Clin Exp Metastasis 2000;18:313-319.

26. Sridhara SU, Choudaha N, Kasetty S, Joshi PS, Kalianpur S, Tijare M. Stromal myofibroblasts in nonmetastatic and metastatic oral squamous cell carcinoma: An immunohistochemical study. J Oral Maxillofac Pathol 2013;17(2):190-194.

27. Yan W, Wistuba II, Emmert-buck RM, Erickson SH. Squamous cell carcinoma-similarities and differences among anatomical sites. Am J Cancer Res 2011; 1(3):275-300

28. Winter J, Kneitz H, Brocker EB. Blood vessel density in basal cell carcinomas and benign trichogenic tumors as a marker for differential diagnosis in dermatopathology. J Skin Cancer 2011Artical ID241382,5 pages

29. Staibano S, Boscaino A, Salvatore G, Orabona P, Palomini I, De Rosa G. The prognostic significance of tumor angiogenesis in nonaggres- sive and aggressive basal cell carcinoma of the human skin. Hum Pathol1996;27(7):695-700.

30. Loggini B, Boldrini L, Gisfredi S, Ursino S, Camacci T, De Jeso K, Cervadoro G, Pingitore R, Barachini P, Leocata P, Fontanini G. CD34 microvessel density and VEGF expression in basal and squamous cell carcinoma. Pathol Res Pract 2003;199(11):705-712

31. Kacar A, Arikok AT, Kokenek Unal TD, Onder E, Hucumenoglu S, Alper M. Stromal expression of CD34, $\alpha$-smooth muscle actin and CD26/ DPPIV in squamous cell carcinoma of the skin: a comparative immunohistochemical study. Pathol Oncol Res 2012;18(1):25-31.

32. Fina L, Molgaard HV, Robertson D, Bradley NJ, Monaghan P, Delia D, Sudherland DR, Baker MA, Greaves MF. Expression of the CD34 gene in vascular endothelial cells.Blood 1990;75(12):2417-2426.

33. Ascani G, Balercia P, Messi M, Lupi L, Goteri G, Filosa A, Stramazzotti D, Pieramici T, Rubini C. Angiogenesis in oral squamous cell carcinoma. Acta Otorhinolaryngol Ital 2005;25(1)13-17.

34. Shivamallappa SM, Venkatraman NT, Shreedhar B, Mohanty L, Shenoy S. Role of angiogenesis in oral squamous cell carcinoma development and metastasis: an immunohistochemical study. Int J Oral Sci 2011;3(4):216-224.

35. Zatterstrom UK, Brun E, Willen R, Kjellen E, Wennerberg J. Tumor angiogenesis and prognosis in squamous cell carcinoma of the head and neck. Head Neck 1995;17(4): 312-318

36. Weidner N. Intratumoral microvassel density as a prognostic factor in cancer. Am J Pathol 1995;147(1):9-19.

37. Vermeulen PB, Gasarini G, Fox SB, Toi M, Martin M, McCulloch P, Pezzella F, Viale G, Weidner N, Harris AL, Ditrix Y. Quantification of angiogenesis in solid human tumors: an international consensus on the methodology and criteria of evaluation. Eur J Cancer 1996;32A(14):24742484.

38. Breuninger H, Black B, Rassner G. Microstaging of squamous cell carcinomas.Am J Clin Pathol 1990;94(5):624-7.

39. Broders AC. Practical points on the microscopic grading of carcinoma. N Y State J Med. 1932; 32: 667-671.

40. Strieth S, Hartschuh W, Pilz L, Fusening NE. Angiogenic switch occurs late in squamous cell carcinomas of human skin. Br J Cancer 2000; 82(3):591-600. 
41. Nico B, BenagianoV, Mangieri D, Maruotti N, Vacca A, Ribatti D. Evaluation of microvascular density in tumors: pro and contra. Histol Histopathol 2008; 23: 601-607

42. Fox SB, Harris AL. Histological quantitation of tumor angiogenesis. APMIS 2004;112:413-30.

43. WeidnerN. Measuring intratumoral microvassel density.Methods Enzymol 2008;444:305-23.

44. Tan WJ, Chia CS, Tan HK, Soo KC, Iyer NG. Prognostic significance of invasion depth in oral tongue squamous cell carcinoma. ORL J Otorhinolaryngol Relat Spec 2012;74(5):264-70.
45. Emerson RE, Ulbright TM, Eble JN, Geary WA, Eckert GJ, Cheng L. Predicting cancer progression in patients with penile squamous cell carcinoma: The importance of depth of invasion and vascular invasion. Mod Pathol 2001;14(10):963-968.

46. Kristensen GB, Abeler VM, Risberg B, Tropé $\mathrm{C}$, Bryne M. Tumor size, depth of invasion, and grading of the invasive tumor front are the main prognostic factors in early squamous cell cervical carcinoma. Gynecol Oncol 1999;74(2):245-251.

\title{
Резиме
}

\section{КОРЕЛАЦИЈА ПОМЕЃУ ГУСТИНАТА НА КРВНИТЕ САДОВИ И МОРФОЛОШКИТЕ КАРАКТЕРИСТИКИ КАЈ ПЛАНОЦЕЛУЛАРЕН КАЦИНОМ НА КОЖА}

\author{
Лена Какашева-Маженковска ${ }^{1}$, Нели Башеска ${ }^{2}$, Симонида Црвенковска ${ }^{3}$, \\ Гордана Петрушевска ${ }^{4}$, Лилјана Миленкова ${ }^{1}$, Весна Јаневска $^{4}$, Владимир Серафимоски $^{5}$ \\ ${ }^{1}$ Институт за МЕП хистологија и ембриологија, Медицински факултет, \\ Универзитет „Св.Кирил и Методиј“, Скопје, Р Македонија \\ 2 Ј3У Универзитетска клиника за радиотерапија и онкологија, лабараторија за хистопатологија и клинич- \\ ка цитологија „Медицински факултет, Универзитет „Св.Кирил и Методиј“, Скопје, Р. Македонија \\ 3 Ј3У Универзитетска клиника за радиотерапија и онкологија, Медицински факултет, \\ Универзитет „Св.Кирил и Методиј“, Скопје, Р. Македонија \\ ${ }^{4}$ Институт за патологија, Медицински факултет, Универзитет „Св. Кирил и Методиј“, \\ Скопје, Р. Македонија \\ ${ }^{5}$ Македонска академија на науките и уметностите,Скопје,Р.Македонија
}

\section{Апстракт}

Вовед: Малигните тумори стимулираат ангиогенеза за да растат и да метастазираат. Туморите со висока ангиогенетска активност се вбројуваат во категоријата на многу агресивни тумори, со неповолна прогноза за пациентите.

Цел на трудот е одредување на густината на крвните садови, т.е. неоваскуларизацијата во инвазивниот фронт на туморската строма кај планоцелуларен карцином на кожата во однос на здравата кожа, како можен показател за туморска прогресија. Одредувана е густината на крвните садови кај планоцелуларен карцином на кожа во однос на длабочината на инвазијата, степенот на хистолошката диференцираност и различната туморска големина на неоплазмите.

Материјал и методи: Материјалот за изведување на ова истражување го сочинуваат оперативни материјали од 30 пациенти со планоцелуларен карцином на кожа, кои биле оперирани. Примероците на ткивата се обработени со стандардна парафинска техника, боени со Hematoxylin-Eosin и имунохистохемиски со антитела за мазен мускулен актин (smooth muscle actin, SMA SMA) и CD34. Густината на крвните садови во инвазивниот фронт на неоплазмата беше споредувана со здравата кожа, туморската големина $\mathrm{p}(\mathrm{T})$, длабочината на инвазијата и степенот на хистолошката диференцираност на туморот $\mathrm{p}(\mathrm{G})$.

Резултати: Хистолошката анализа покажа висока статистичка разлика во густината на крвните садови кај планоцелуларниот карцином на кожа во споредба со здравата кожа и статистички разлики во густината на крвните садови во однос на длабочината на инвазија и степенот на диференцираност на неоплазмата. Слабата диференцираност на неоплазмата и зголемената длабочина на инвазијата покажуваат зголемување на неоваскуларизацијата.

Клучни зборови: планоцелуларен карцином, имунохистохемија, SMA, CD34, густина на неоваскуларизација, инвазивен фронт, хистолошка диференцијација 